\title{
Pola Komunikasi Antarbudaya di Kelurahan Kampung Jawa Kecamatan Curup Tengah Kabupaten Rejang Lebong
}

\author{
Yuli Puspita Sari \\ IAIN Curup \\ Wiwipuspita05@gmail.com
}

\begin{abstract}
This study explores or discusses the intercultural communication patterns found in the villages of the java in the sub district of Curup in the Central District of Rejang Lebong. There are five tribes in the village of Javanese village, namely the tribe of Lembak, Padang, Rejang, Java, Musi. Cultural differences that exist in the villages of the village of java do not lead to conflict and intercultural divisions, they respect each other from these disffences, but they see that their daily lives are closed and ignorant. The purpose of this study was to find out how the process of intercultural communication patterns in the villages of ward java communicate with different cultural backgrounds. The menhod used by the researcher is descriptive qualitative approach is used because the data needed by the author is only in the form of information and explanation from the informant. The data needed in this study was obtained through information from the village government, community leader, and the surrounding community. In data collection researchers used several techniques, namely observation, interviews, and documentation. The collected data is analyzed by data resuctio, data presentation (display), and verivikasi of data or drawing conclusions. From the results of the study it can be concluded that the intercultural communication patterns in the villages of the village of Java are obtained by the star's communication pattern. Draving factors for intercultural communication are messages that are easy to understand, positive perception, and the same language.
\end{abstract}

Keywords: Patterns, Intercultural Communication, The Village of Java

\begin{abstract}
Abstrak
Penelitian ini mengkaji atau membahas tentang pola komunikasi antarbudaya yang terdapat di kelurahan kampung Jawa kecamatan Curup Tengah kabupaten Rejang Lebong. Terdapat lima suku di kelurahan kampung Jawa yaitu suku Lembak, Padang, Rejang, Jawa, Musi. Berbedaan budaya yang ada di Kelurahan Kampung Jawa tidak menimbulkan konflik, dan perpecahan antarbudaya, mereka saling mengahargai dari perbedaan tersebut namun dilihat kesehariannya masyarakat terlihat tertutup dan cuek. Tujuan dari penelitian ini adalah untuk mengetahui bagaimana proses pola

Jurnal Dakwah dan Komunikasi

IAIN Curup-Bengkulu | E-ISSN: 2548-3366; P-ISSN: 2548-3293
\end{abstract}


komunikasi antarbudaya masyarakat kelurahan kampung Jawa berkomunikasi yang memilki latar belakang budaya yang berbeda. Metode yang digunakan oleh peneliti yaitu deskriptif kualitatif pendekatan ini digunakan karena data yang dibutuhkan penulis hanya berupa keterangan dan penjelasan dari informan.Data yang diperlukan dalam penelitian ini diperoleh melalui informasi pemerintah kelurahan, tokoh masyarakat, dan masyarakat sekitar.Dalam pengumpulan data peneliti menggunakan beberapa teknik yaitu observasi, wawancara, dan dokumentasi. Data yang terkumpul di analisis dengan reduksi data, sajian data (Displey), dan verifikasi data atau menarik kesimpulan.Dari hasil penelitian dapat disimpulkan pola komunikasi antarbudaya di kelurahan kampung Jawa diperoleh adalah pola komunikasi bintang. Faktor pendorong komunikasi antarbudaya pesan yang mudah dipahami, persepsi positif dan penggunaan bahasa yang sama.

Kata kunci : Pola, Komunikasi Antarbudaya, Kelurahan Kampung Jawa

\section{Pendahuluan}

Esensi komunikasi terletak pada proses, yakni suatu aktivitas yang melayani hubungan antara pengirim dan penerima pesan melampaui ruang dan waktu. Sebab, mengapa semua orang pertama-tama tertarik mempelajari komunikasi manusia (buman communication), sebuah proses komunikasi yang melibatkan manusia pada kemarin, kini dan mungkin di masa yang akan datang. Dalam kamus bahasa Indonesia pola berarti gambar, bentuk, sistem, cara kerja, model, rancangan. ${ }^{1}$ Menurut Tubbs dan Moss mengatakan bahwa pola komunikasi atau hubungan itu dapat diciptakan oleh komplementaris atau simetri. Dalam hubunngan komplementer, satu bentuk perilaku akan diikuti oleh lawannya. Contohnya perilaku dominan dari satu partisipan mendatangkan perilaku tunduk dan lainnya.Dalam simetri, tingkatan sejauh mana orang berinteraksi atas dasar kesamaan.Dominasi bertemu dengan dominasi atau kepatuhan dengan kepatuhan. Disini kita mulai melibatkan bagaimana proses interaksi menciptakan struktur sistem. Bagaimana orang merespon satu sama lain menentukan jenis hubungan yang mereka miliki.

Adapun maksud penulis "pola komunikasi" disini terkait dalam judul ini adalah suatu cara, bentuk komunikasi antara komunikan dan komunikator yang saling mempengaruhi sikap dan perilaku satu sama lain dengan latar belakang berbeda kebudayaan melalui media tertentu. Komunikasi dan budaya merupakan dua konsep utama yang mewarnai komunikasi antarbudaya (interculture communication),

${ }^{1}$ Departemen Pendidikan dan kebudayaan, Kamus Besar Bahasa Indonesia, (Jakarta : Balai Pustaka, 1996), h. 885 
yaitu konsep kebudayaan dan konsep komunikasi. ${ }^{2}$ Budaya adalah suatu pola hidup menyeluruh.Budaya bersifat kompleks, abstrak, dan luas.Banyak aspek budaya yang turut menentukan perilaku komunikasi.

Komunikasi dan budaya merupakan dua konsep utama yang mewarnai komunikasi antarbudaya (interculture communication), yaitu konsep kebudayaan dan konsep komunikasi. ${ }^{3}$ Budaya adalah suatu pola hidup menyeluruh.Budaya bersifat kompleks, abstrak, dan luas.Banyak aspek budaya yang turut menentukan perilaku komunikasi.Unsur-unsur sosio-budaya ini tersebar dan meliputi banyak kegiatan sosial manusia.Komunikasi adalah sebuah proses penyampaian pesan dari komunikator kepada komunikan melalui saluran tertentu. Ada pula yang menyebutkan komunikasi sebagai suatu proses penyampaian pesan (berupa lambang, suara, gambar, dan lain-lain) dari suatu sumber kepada sasaran (audience) dengan menggunakan saluran tertentu 4 .

Masyarakat yang tinggal pada lingkungan yang sama sering kita jumpai memiliki latar belakang yang berbeda kebudayaan. Tidak menutup kemungkinan mereka tentu berkomunikasi, berintraksi satu sama lain hubungan komunikasi dan budaya sangat penting dipahami karena tujuan komunikasi antarbudaya adalah efektifitas antarbudaya dalam kenyataan sosial disebutkan bahwa manusia tidak dapat dikatakan berintraksi sosial kalau individu tidak berkomunikasi. Demikian pula dapat dikatakan bahwa intraksi antarbudaya sangat tergantung dari komunikasi antarbudaya. Konsep ini sekaligus menerangkan bahwa tujuan komuniakasi antarbudaya akan tercapai (komunikasi yang sukses) bila bentuk-bentuk hubungan antarbudaya menggambarkan upaya yang sadar dari peserta komunikasi untuk memperbarui relasi antara komunikator dan komunikan, menciptakan lahirnya semangat kesetiakawanan, persahabatan. ${ }^{5}$

Di Kabupaten Rejang Lebong Kelurahan Kampung Jawa Kecamatan Curup Tengah, wilayah ini berbagai masyarakat dengan latar belakang budaya yang berbeda tinggal disana. Tidak menutup kemungkinan komunikasi antarbudaya masyarakat sering terjadi dan mereka hidup berdampingan. Kondisi masyarakat di Kelurahan Kampung Jawa terlihat cuek, kurangnya pergaulan antara masyarakat pribumi dan masyarakat pendatang di sana jika dilihat sehari-harinya.Keadaan tersebut dikarena Sebagian masyarakat sibuk dengan kegiatan masing-masing dan pekerjaan.Masyarakat Kelurahan Kampung Jawa berdominan bermata pencarian

\footnotetext{
${ }^{2}$ Alo Liliweri, Gatra-Gatra Komunikasi Antarbudaya, (Yogyakarta: Pustaka Pelajar, 2011), 8 .

${ }^{3}$ Alo Liliweri, Gatra-Gatra Komunikasi Antarbudaya, (Yogyakarta : Pustaka Pelajar, 2011), h. 8 2006), h. 3

4 Tommy Suprapto, Pengantar Teori Komunikasi,( Yogyakarta : Media Pressindo, ${ }^{5}$ Ibid., h. 21
} 
berkebun yang jarang terlihat membuat lingkungan kelurahan Kampung Jawa sering terlihat sepi sehari-hari.

Dari perbedaan yang mereka miliki seperti rasa, suku, budaya dan etnik tidak pernah terjadi konflik antarbudaya di kelurahan kampung Jawa.Justru perbedaan yang mereka miliki menjadi hal penyatu, hidup rukun, dan harmonis meskipun secara langsung masyarakat pendatang di wajibkan mengikuti adat istiadat suku Rejang dan itu di terima sangat positif bagi seluruh masyarakat pendatang. Maka dari itu penulis tertarik untuk meneliti kelurahan kampung Jawa dari segi pola komunikasi antrabudaya.

Dari perbedaan-perbedaan yang terjadi mulai adat istiadat serta budaya yang dimiliki, apabila tingkat perbedaan antara unsur kebudayaan yang dimiliki setiap individu maka tingkat perbedaan komunikan dan komunikator memiliki persepsi yang berbeda. Pada saat masyarakat berkomunikasi yang berbeda kebudayaan sebenarnya, pola-pola persepsi dan perilaku yang diterima, diakui satu sama lain diharapkan sebagai identitas kelompok disebut kebudayaan. Maka dari itu kebudayaan dijadikan identitas kelompok budaya, maka seorang salah satu individu tersebut sudah menunjukkan pola-pola perilaku kelompok dan sejak itu pula tanpa disadari terkadang kelompok tersebut dinyatakan telah mengambarkan, memberikan, makna kebudayaannya dari perilaku atau reaksi.

Adapun pertanyaan dalam penelitian ini sebagai berikut :

1. Bagaimana pola komunikasi antarbudaya dalam proses komunikasi di Kelurahan Kampung Jawa kecamatan Curup Tengah Kabupaten Rejang Lebong?

2. Apa faktor pendukung komunikasi antarbudaya dalam proses komunikasi di Kelurahan Kampung Jawa kecamatan Curup Tengah Kabupaten Rejang Lebong?

Adapun Tujuan Penelitian dalam penelitian ini adalah :

1. Untuk mengetahui dan memahami proses pola komunikasi antarbudaya di kelurahan Kampung Jawa Kecamatan Curup Tengah Kabupaten Rejang Lebong.

2. Untuk mengetahui dan memahami faktor pendukung komunikasi antarbudaya di kelurahan Kampung Jawa Kecamatan Curup Tengah Kabuapten Rejang Lebong.

Manfaat Penelitian ini adalah sebagai berikut :

1. Manfaat Teoritis

Penelitian ini diharapkan dapat memperkaya wawasan dan ilmu komunikasi khususnya di bidang ilmu Komunikasi Penyiaran Islam (KPI) melalui konsep komunikasi antarbudaya dan metode penelitian kualitatif deskritif bagi mahasiswa yang ingin mengetahui lebih dalam bagaimana pola komunikasi 
antarbudaya. Serta menambah wawasan untuk referensi bagi mahasiswa yang mempunyai usulan skripsi dengan tema yang serupa dengan peneliti.

2. Manfaat Praktis

Penelitian ini diharapkan dapat memberikan masukan kepada masyarakat dan menjadi bacaan ilmiah bagi mahasiswa komunikasi dan penyiaran islam, dari hasil penelitian ini dapat bermanfaat dalam memperkaya kajian ilmu kosmunikasi antarbudaya.

\section{Landasan Teoritis}

a. Pengertian Pola Komunikasi

Pola adalah bentuk atau model (lebih abstrak, suatu set peraturan) yang biasa di pakai untuk membuat atau untuk menghasilkan suatu atau bagian dari sesuatu, khususnya jika yang di timbulkan cukup mencapai suatu sejenis untuk pola dasar yang dapat di tunjukkan atau terlihat. ${ }^{6}$ Soenarto menurutnya pola komunikasi merupakan Dimensi pola komunikasi terdiri dari dua macam, yaitu pola yang berorientasi pada konsep dan pola yang berorientasi pada sosial yang mempunyai arah hubungan yang berlainan.

Tubbs dan Moss mengatakan bahwa pola komunikasi atau hubungan itu dapat diciptakan oleh komplementaris atau simetri. Dalam hubunngan komplementer, satu bentuk perilaku akan diikuti oleh lawannya. Contohnya perilaku dominan dari satu partisipan mendatangkan perilaku tunduk dan lainnya.Dalam simetri, tingkatan sejauh mana orang berinteraksi atas dasar kesamaan. Dominasi bertemu dengan dominasi, atau kepatuhan dengan kepatuhan Disini kita mulai melibatkan bagaimana proses interaksi menciptakan struktur sistem. Bagaimana orang merespon satu sama lain menentukan jenis hubungan yang mereka miliki.

Mudjito menurutnya pola komunikasi itu ada empat pola komunikasi, yaitu pola komunikasi roda, pola komunikasi rantai, oila komunikoasi lingkaran, pola bintang. Keempat pola tersebut dapat dilihat pada gambar berikut:

1. Pola roda

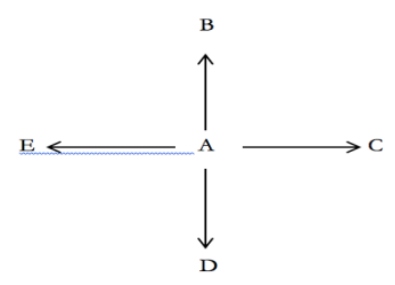

Gambar Pola Roda maret 2017 .

${ }^{6}$ bttp://mwn.irmanfsp.com/2017/03/pola-komunikasi-antar-budaya.btml, di akses 
2. Pola lingkaran

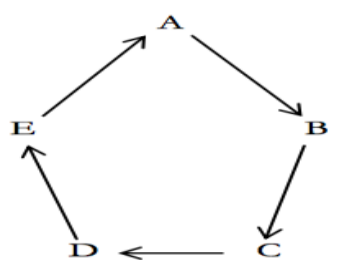

Gambar Pola Lingkaran

3. Pola Rantai

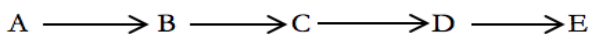

Gambar Pola Rantai

4. Pola Bintang

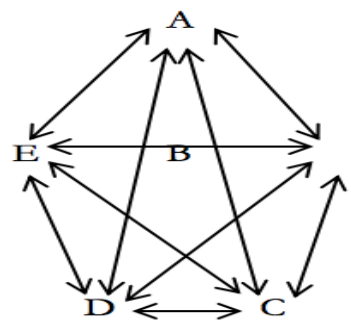

Gambar Pola Bintang

Penjelasan :

a. Pola roda, seseorang berkomunikasi pada banyak orang, yaitu : B, C, D, dan E.

b. Pola lingkaran, hampir sama pada pola rantai, namun orang terakhir E berkomunikasi pula kepada orang pertama A

c. Pola rantai, seseorang (A) berkomunikasi pada seorang yang lain (B), dan seterusnya ke (C), ke (D), dan ke (E).

d. Pola bintang, semua anggota berkomunikasi dengan semua anggota

b. Pengertian Komunikasi Antarbudaya

Istilah komunikasi berpanggkal pada perkataan latin Communisyang artinya membuat kebersamaan atau membangun kebersamaan antara dua orang atau lebih. Komunikasi juga berasal dari akar kata dalam bahasa latinCommunico 
yang artinya membagi. ${ }^{7}$ Ilmu komunikasi, apabila diaplikasikan secara benar akan mampu mencegah dan menghilangkan konflik antarpribadi, antarkelompok, antarsuku, antarbangsa dan antarras, membina kesatuan, dan persatuan umat manusia penghuni bumi. ${ }^{8}$ Pengertian komunikasi menurut beberapa para ahli :

1. Joseph A. Devito menurutnya komunikasi adalah kegiatan yang dilakukan oleh seseorang atau lebih, yakni kegiatan menyampaikan dan menerima pesan, yang mendapat distorsi dari gangguan-gangguan, dalam suatu konteks, yang menimbulkan efek dan kesempatan untuk arus balik.

2. Carl I. Hovland, ilmu komunikasi adalah upaya yang sistematis untuk merumuskan secara tegar asas-asas penyampaian informasi serta pembentukan pendapat dan sikap. ${ }^{9}$

3. Alo Liliweri menurutnya komunikasi dapat diartikan sebagai proses peralihan dan pertukaran informasi oleh manusia melalui adaptasi ke dalam sebuah sistem kehidupan manusia dan lingkungannya. Proses peralihan dan petukaran informasi itu dilakukan melalui simbol-simbol bahasa verbal maupun nonverbal yang dipahami bersama. ${ }^{10}$

4. Rihard E. Porter dan Larry A. Samovar, bahwa asumsi dasar komunikasi berhubungan dengan perilaku manusia dan kepuasan terpenuhinya kebutuhan berintraksi dengan manusia-manusia lainnya. ${ }^{11}$

Kata "kebudayaan" berasal dari bahasa sanserkerta buddhayah yaitu bentuk jamak dari buddhi yang berarti budi atau akal.Dengan demikian kebudayaan dapat diartikan sebagai hal-hal yang bersangkutan dengan akal. Ada ahli antropologi lain yang berpendapat kata budaya sebagai suatu perkembangan dari majemuk budi-daya, yang berarti daya dari budi yang berupa cipta, karsa, dan rasa, sedangkan kebudayaan adalah hasil dari cipta, karsa dan rasa itu. Namun, dalam istilah antropologi budaya perbedaan itu ditiadakan. Kata budaya hanya dipakai sebagai suatu singkatan dari kebudayaan dengan arti yang sama. ${ }^{12}$

Budaya merupakan suatu cara hidup yang berkembang dan dimiliki bersama oleh sebuah kelompok orang dan diwariskan dari generasi ke generasi. Budaya terbentuk dari banyak unsur yang rumit, termaksuk sistem agama dan politik, adat istiadat, bahasa, perkakas, pakaian, bangunan, dan karya seni. Seseorang yang memiliki cara berpakaian, hubunganya dengan orang tua dan teman1998), 17

${ }^{7}$ Hafied Cangara, Pengantar Ilmu Komunikasi, (Jakart: PT. Raja Grafindo Persada,

${ }^{8}$ Onong Uchjana, Ilmu Komunikasi Teori dan Praktek, (Bandung: PT. Remaja Rosdakarya, 2013), 10

${ }^{9}$ Onong Uchjana, Op.Cit., 27

10 Alo Liliweri, Gatra-Gatra Komunikasi Antarbudaya, (Yogyakart: Pustaka Pelajar, 2011), 5

${ }^{11}$ Bakti Komalasari, dan Adinda Tessa Naumi, Komunikasi Antarbudaya, (Curup: Lp2 STAIN Curup, 2013), 4

${ }^{12}$ Ibid., 21 
temannya, apa yang diharapkan dari perkawinan dan perkerjaan, makanan yang dimakan, bahasa yang digunkan, semuanya dipengaruhi oleh budaya. Tidak semua anggota budaya memiiki semua unsur budaya secara bersama. Selain itu sebuah budaya akan berubah dan berevolusi dari waktu ke waktu. Namun, seperangkat karakteristik dimiliki bersama oleh sebuah kelompok secara keseluruhan dan dapat dilacak, meskipun telah berubah banyak dari generasi ke generasi. ${ }^{13}$

\section{Metode Penelitian}

a. Jenis Penelitian

Untuk memudahkan peneliti dalam mendapatkan data yang berhubungan dalam permasalahan penelitian ini maka peneliti menggunakan jenis penelitian kualitatif dengan pendekatan deskriftif.Jenis penelitian ini adalah penelitian lapangan (field research) dengan penelitian kualitatif berbentuk deskriptifyaitu penelitian yang dilakukan dalam setting tertentu yang ada dalam kehidupan real (alamiah) dengan maksud menginvestigasi dan memahami fenomena. ${ }^{14}$ Pendekatan kualitatif adalah suatu proses penelitian dan pemahaman yang berdasarkan metode yang menyelidiki suatu fenomena sosial dan masalah manusia. Bogdan dan Taylor sebagaimana dikutip oleh Moleong mengemukan bahwa metodologi kualitatif merupakan prosedur penelitian yang menghasilkan data deskriptif berupa kata-kata tertulis maupn lisan dari orang-orang dan perilaku yang diamati. ${ }^{15}$

Pada pendekatan ini, peneliti membuat suatu gambaran kompleks, meneliti kata-kata, laporan terinci dari pandangan responden, dan melakukan studi situasi yang alami. ${ }^{16} \mathrm{Pada}$ saat penelitian di kelurahan Kampung Jawa secara langsung. Daripenjelasan di atas maka dapat disimulkan tujuan utama peneliti dalam menggunakan metodologi ini adalah menggambarkan dan mengamati keadaan masyarakat keluraahan Kampung Jawa, satu lingkungan tempat tinggal yang berbeda budaya, dilihat dari komunikasi satu sama lain sehingga terdapat berubahan sikap yang ditimbulkan, apa efek dari berubahan sikap tersebut dalam lingkungan mereka bermasyarakat.

${ }^{13}$ Stewart L. Tubb, Sylvia Moss, Human Comunication Konteks-konteks Komunikasi, (Bandung: PT. Remaja Rosdakarya, 2005), 237

${ }^{14}$ Koentjaradinigrat, Metode-Metode Penelitian Masyarakat, (Jakart: Gramedia, 1997), 5

${ }^{15}$ Lexy J.Moleong, Metodologi Penelitian Kualitatif, Edisi Revisi (Bandung: PT. Rosda Karya, 2006), 3

${ }^{16}$ Sukarman Syarnubi, Metodologi Penelitian Kuantitatif dan Kualitatif, (Lembaga Penerbit dan Percetakan (Lp2) STAIN Curup), 164 
b. Subjek dan Objek Penelitian

Subjek penelitian yaitu individu, benda, atau organisme yang dijadikan sumber informasi yang dibutuhkan dalam pengumpulan data penelitian.Subjek penelitian merupakan informan atau responden, yakni orang memberikan info mengenai data yang di harapkan peneliti barkaitan dengan penelitian yang sedang dilaksanakannya atau sanggup dinamakan sebagai subjek penelitian atau responden (kuantitatif). ${ }^{17}$

Subjek dari penelitian ini adalah tokoh agama Ibnu Hasan dan Hasani, tokoh masyarakat Mirza fahrizal, serta masyarakat yang tinggal di kelurahan Kampung Jawa Kecamatan Curup Tengah kabupaten Rejang Lebong sebagai objek yang akan diteliti untuk memperoleh data yang akan diperlukan.

c. Sumber Data

\section{Data Primer}

Data primer merupakan sumber data yang langsung memberikan data kepada pengumpul data. ${ }^{18}$ Sumber data primer ini dikumpulkan langsung oleh peneliti dari objek penelitian ini berupa data wawancara yang diajukan kepada perangkat kelurahan kampung Jawa, tokoh agama dan tokoh adat serta masyarakat sebagai informan yang memberikan informasi relevan dengan masalah penelitian ini di kelurahan kampung Jawa.

\section{Data Sekunder}

Data sekunder merupakan sumber yang tidak langsung memberikan data kepada pengumpul data, misalnya lewat orang lain atau lewat dokumen. ${ }^{19}$ Data sekunder ini dikumpulkan peneliti untuk penunjang data penelitian sebagai data yang memperkuat masalah yang dihadapi di wilayah yang akan diteliti. Adapun data sekunder di maksud disini adalah melalui internet, data-data hasil survei, data-data penting sebagai penunjang, penguat dari data primer yang telah peneliti dapat yang berhubungan dengan masalah yang akan di teliti.

\section{c. Teknik Pengumpulan Data}

Untuk memudahkan penelitian ini, penulis menggunakan beberapa metode penelitan:

${ }^{17}$ http:/ / markasfisika.blogspot.com/2017/12/pengertian-subyek-penelitiankualitatif.btml, di akses 12 april 2017 2014), 225

${ }^{18}$ Sugiyono, Metode Penelitian Kuantitatif Kualitatif dan $\mathrm{R} \& \mathrm{D}$, (Bandung: Alfabeta,

${ }^{19}$ Ibid., 225 
1. Observasi

Dalam penelitian kualitatif, peneliti mengadakan pengamatan dan mengumpulkan data secara langsung dari lapangan. Pada waktu dilapangan peneliti membuat "catatan" setelah pulang kerumah atau ketempat tinggal barulah menyusun "catatan lapangan"

2. Interview (wawancara)

Esterberg sebaimana dikutip oleh Sugiyono mendefinisikan interview “" a meeting of two persons to exchange information and idea through question and responses, resulting in communication and joint construction of meaning about a particular topic”. Wawancara adalah merupakan pertemuan antara dua orang untuk bertukar informasi dan ide melalui Tanya jawab, sehingga dapat dikontruksikan makna dalam suatu topik tertentu. ${ }^{20}$

Jadi dengan wawancara, maka peneliti akan mengetahui hal-hal yang lebih mendalam tentang partisipasi dalam menginterprentasikan situasi dan fenomena yang terjadi, di mana hal ini tidak bisa ditemukan melalui observasi. $^{21}$

3. Dokumentasi

Studi dokumen merupakan pelengkap dari penggunaan observasi dan wawancara dalam penelitian kualitatif.Dokumentasi yang dimaksudkan peneliti disini berupa kegiatan-kegiatan masyarakat yang mencerminkan pola-pola komunikasi antarbudaya, hasil wawancara, data-data yang berbentuk gambar, dan dokumentasi digunakan peneliti untuk melengkapi data-data penelitian. ${ }^{22}$ Setelah observasi dan wawancara yang dilakukan data dokumentasi digunakan sebagai memperkuat dari data yang di dapat peneliti.

\section{d. Teknik Analisis Data}

Setelah data terkumpul metode analisis data yang digunakan adalah analisis deskri ptif kualitatif artinya menganalisa keadaan dan menginterpretasikan data dengan cara menggambarkan dan melukiskan keadaan subyek, obyek dan datadata yang lain dalam penelitian pada saat sekarang berdasarkan fakta yang ada. ${ }^{23}$ Analisi data merupakan upaya mencari dan menata secara sistematis catatan hasil obsevasi, wawancara, dan lainnya untuk menigkatkan pemahaman peneliti tentang kasus yang diteliti dan menyajikannya sebagai temuan bagi orang lain. ${ }^{24}$

${ }^{20}$ Ibid., 231

${ }^{21}$ Ibid., 233

22Sugiyono, Op. Cit., 240

${ }^{23}$ Handari Nawawi, Metodologi Penelitian Bidang Sosial, (Yogyakarta: Gajah Mada University Press, 1990), h. 63.

${ }^{24}$ Noeng Muhadjir, Metodologi Penelitian Kualitatif, (Yogyakarta: Rake Sarasin, 1998), 104. 
Adapun teknik analisis data yang digunakan peneliti sebagai berikut :

a. Reduksi data (Reduction)

Pada tahap ini dilakukan proses penyederhanaan dan pengkatagorian data. Mereduksi artinya data yang telah diperoleh peneliti memilah-milah berupa memilih hal-hal yang pokok, memfokuskan pada hal-hal yang penting dan membuang hal-hal yang tidak diperlukan peneliti.

b. Sajian data (Display)

Merupakan proses menampilkan data hasil reduksi dan kategorinisasi dalam matriks berdasarkan kriteria tertentu. Data ini dapat berupa data dalam bentuk uraian tertentu, sebuah bagain dan lain sebagainya sehingga memudahkan peneliti dalam menyusun rancangan penelitian selanjutnya.

\section{c. Verifikasi data (Conclusion Drawing)}

Verifikasi data atau penarikan kesimpulan, apabila hasil displey data menunjukkan bahwa data yang diperoleh telah cukup dan sesuai dengan informasi yang telah dibutuhkan, maka peneliti mulai melakukan penarikan kesimpulan menggunakan teori dan hasil data lapangan 25

\section{Hasil Penelitian dan Pembahasan}

Penelitian ini berfokus pada pola komunikasi antarbudaya.Kelurahan Kampung Jawa kecamatan Curup Tengah merupakan daerah yang ada di Kabupaten Rejang Lebong. Dari pemekaran wilayah merupakan awal mula nama kelurahan ini dinamai kelurahan kampung Jawa dan banyak masyarakat yang sepakat menamainya, karna dilatar belakangi banyaknya warga yang pendatang bersuku Jawa yang menetap bukan suku pribumi yakni suku Rejang. Itulah mengapa nama kelurahan ini disebut kelurahan kampung Jawa. Menurut Mujito pola komunikasi ada empat macam yaitu pola roda, pola rantai, pola lingkaran dan pola bintang.

Sebagai makhluk sosial, kita sering berintraksi dengan orang lain. Mula-mula intraksi tersebut kita lakukan didalam keluarga.Kemudian kita mulai berkembang ke sistem sosial yang lebih besar lagi, hal ini dikarenakan kita memiliki lingkungan tempat tinggal yang berhubungan dengan tetangga sebelah rumah, tetangga sekampung, sedesa, sekecamatan dan seterusnya. Didalam setiap sistem sosial itu terdapat kebiasaaan-kebiasaan, nilai-nilai, norma-norma yang tidak lain adalah unsurunsur budaya di suatu masyarakat yang bersangkutan.

Masyarakat dan budaya merupakan hal yang sangat komplek dan terdiri atas berbagai orientasi budaya yang saling berhubungan.Pembahasan tentang nilai, kepercayaan, dan orientasi lainnya secara kolektif merupakan pola budaya.Pola komunikasi merupakan serangkaian aktivitas menyampaikan pesan sehingga

${ }^{25}$ http:/ / dosensosiologi.com/teknik-analisis-data-kualitatif-kualitatif-lengkeap/ di akses 5 Februari 2018 
diperoleh feedback dari penerima pesan. Dari proses komunikasi tersebut, akan timbul pola, bentuk dan juga bagian-bagian kecil yang berkaitan erat dengan pola komunikasi antarbudaya.

Dalam kehidupan manusia tidak terlepas dari komunikasi. Komunikasi sangat penting di pahami dalam bermasyarakat terutama pada masyarakat yang berbeda- beda budaya. Seperti komunikasi, manusia juga tidak terlepas dari budaya yang dimilikinya. Budaya juga dapat menjadi ciri khas seseorang mulai dari penampilan atau gaya hidup, makanan, melalui bahasa dalam kehidupan sehari-hari dan lain sebaginya serta kebudayaan diwariskan secara turun temurun oleh setiap individu.

Budaya yang dimiliki setiap individu akan menampakkan diri dalam polapola bahasa, dalam bentuk-bentuk kegiatan dan perilaku yang berfungsi sebagai bentuk tindakan-tindakan penyesuaian diri dan gaya komunikasi yang memungkinkan orang-orang tinggal dalam suatu masyarakat di suatu lingkungan geografis tertentu pada suatu tingkat perkembangan teknis tertentu dan pada suatu saat tertentu. ${ }^{26}$

Komunikasi antarbudaya sangat penting untuk kita pahami agar dapat berkomunikasi secara efektif dan menyenangkan. Komunikasi antarbudaya merupakan proses komunikasi antara orang dari budaya yang berbeda. Pola komunikasi antarbudaya yang ada di desa kampung Jawa Kec. Curup Tengah sangatlah unik, dimana budaya-budaya yang ada mempersatukan warga bukan mengundang konflik hal ini dapat dilihat pada saat mereka saling berintraksi dan berkomunikasi dalam penggunaan simbol-simbol tertentu (komunikasi verbal) dalam penggunaan bahasa, adanya feedback atau umpan balik yaitu terjadinya arus dari komunikan dan komunikator sehingga adanya perubahan sikap atau komunikasi non verbal, komunikan dan komunikator sebagai penentu utama keberhasilan dalam komunikasi. Untuk mengetahui bagaimana komunikasi antarbudaya di desa Kampung Jawa peneliti telah melakukan penelitian dengan melakukan wawancara terhadap masyarakat desa Kampung Jawa di antaranya sebagai berikut :

\section{a. Komunikasi Verbal}

Komunikasi verbal merupakan pesan atau simbol-simbol yang akan dilakukan secara sadar oleh individu untuk berhubungan dengan orang lain secara lisan. Suatu sistem kode verbal disebut bahasa.Bahasa dapat didefinisikan sebagai seperangkat simbol, dengan aturan untuk mengkombinasikan simbolsimbol tersebut, yang digunakan dan dipahami suatu komunitas. ${ }^{27}$

Apabila terjadi komunikasi tentu adanya unsur-unsur komunikasi seperti komunikan, komunikator, pesan yang akan di sampaikan, dan feedback atau respon. Dalam hal ini komunikasi yang efektif antara komunikan dan komunikator perlu memahami bahasa yang di gunakan satu sama lainnya agar

\footnotetext{
${ }^{26}$ Deddy Mulyana, Jalaluddin Rahmat, Komunikasi Antarbudaya Panduan Komunikasi Dengan Orang-orang Berbeda Budaya, (PT. Remaja Rosdakarya Bandung, 2014), 18

${ }^{27}$ Bakti Komalasari, Adinda Tessa Naumi, Komunikasi Antarbudaya, ( Curup: Lp2 STAIN Curup, 2013), h. 112
} 
tidak terjadinya noise (gangguan). Dari bahasa yang gunakan dalam komunikasi apabila antara komunikan dan komunikator tidak memahami bahasa yang digunakan satu sama lain tentu akan menghambat efektifitas berkomunikasi.

Dalam komunikasi tentu tidak terlepas dari bahasa yang digunakan agar komunikasi berlangsung secara efektif.Bahasa merupakan identitas, karena dalam berbahasa terdapat dialek dan aksen yang dapat memperkuat identitas individu.Identitas ini dapat dijadikan pembeda antara ras, entik, budaya, perilaku, adat-istiadat, kelompok budaya, yang dimiliki seseorang dengan individu lainnya.Seperti aku dan dia, aku dan mereka.Begitu pentingnya komunikasi verbal karena tanpa komunikaasi ini aktivitas tidak dapat berfungsi dengan baik. Komunikasi verbal terdiri atas dua bagian yaitu :

1) Komunikasi verbal satu arah adalah komunikasi yang berlamgsung pada satu pihak saja.

2) Komunikasi verbal dua arah adalah komunikasi yang bersifat timbal balik atau feedback

\section{b. Komunikasi Non Verbal}

Komunikasi non verbal dapat dilihat pada saat komunikan maupun komunikator saling berkomunikasi melalui pesan verbal yang disampaikankan komunikator.Komunikasi non verbal ini merupakan komunikasi yang tidak di sampaikan dengan menggunkan kata-kata. Contoh komunikasi non verbal disini misalnya menggunkan gerak isyarat, bahasa tubuh, eksperi wajah, cara berbicara seperti intonasi, penekanan, kualitas suara, dan gaya emosi yang dapat kita lihat pada saat berkomuniksi. Misalnya secara sentuhan dapat termaksuk bersalaman, menggenggam, sentuhan di punggung, mengelus-elus, pukulan dan lain-lain.

Komunikasi non verbal juga bisa menggunakan objek tertentu seperti pakaian, simbol-simbol tertentu (gaya bicara, penekanan pengucapan maupun intonasi). Menurut Larry A. Samovar dan Richard E. Porter, komunikasi non verbal mencakup semua ransangan (kecuali ransangan verbal dalam suatu setting komunikasi, yang dihasilkan oleh individu dan menggunkan lingkungan oleh individu, yang mempunyai nilai pesan potensial bagi pengirim atau penerima, jadi definisi ini mencakup perilaku yang disengaja juga sebaliknya sebagi bagian peristiwa komunikasi secara keseluruhan. ${ }^{28}$

Dalam komunikasi ada 3 tujuan komunikasi non verbal :

1. Kita berusaha meningkatkan pemahaman mengenai sifat dan fungsi komunikasi non verbal.

2. Berusaha meningkatkan pemahaman terhadap diri sendiri dan terhadap orang lain sebagai komunikator non verbal.

3. Kita berusaha meningkatkan kemampuan kita untuk berkomunikasi secara lebih efektif sebagai pengirim dan penerima pesan-pesan nonverbal.

Fungsi komunikasi non verbal antara lain :

1. Untuk menekankan

Kita menggunakan komunikasi non verbal untuk menonjolkan atau menekankan beberapa bagian dari pesan verbal.

${ }^{28}$ Ibid., h. 122 
2. Untuk melengkapi (complement)

Kita juga menggunakan komunikasi non verbal untuk memperkuat warna atau sikap umum yang dikomunikasikan oleh pesan verbal.Misalnya tersenyum dalam menceritkan hal yang lucu.

3. Untuk menunjukkan kontradiksi

Kita juga dapat secara sengaja mempertentangkan pesan verbal kita dengan gerakkan non verbal.Misalnya menyilangkan jari atau mngedipkan mata untuk menjunjukkan bahwa yang dikatan salah.

4. Untuk mengatur

Gerak-gerik non verbal dapat mengendaalikan atau mengisyaratkan keinginan untuk mengatur arus pesan verbal.

5. Untuk menggulanggi

Dapat menggulangi atau merumuskan ulang makna dari pesan verbal. Misalnya menyertai peryataan verbal “ apa benar?” dengan mengangkat alis mata

6. Untuk mengantikan

Komunikasi non verbal juga dapat mengantikan pesan verbal.Misalnya mengatkan iya dengan mengganggukkan kepala. ${ }^{29}$

Komunikasi non verbal yang terjadi di desa kampung Jawa dalam komunikasi antarbudaya yang dapat dilihat dari sudut pandang berupa kegiatankegiatan yang diwajibkan bagi setiap warga untuk dilakukan dengan menggunakan adat istiadat budaya Rejang. Jika dari segi bahasa yang gunakan komunikasi verbal mereka tidak ada hambatan dalam memahami pesan verbal tentu saja, komunikasi non verbal menjadi penujang akan kelancaran, keakraban, pada saat komunikasi berlangsung karna komunikasi non verbal terkadang terlihat bersamaan dengan komunikasi verbal. Misalnya saja berkata menyapa dengan senyuman.

Komunikasi antarbudaya merupakan proses komunikasi antara orang dari budaya yang berbeda. Komunikasi antarbudaya yang ada di Kelurahan Kampung Jawa Kecamatan Curup Tengah, dimana budaya-budaya yang ada mempersatukan warga bukan mengundang konflik hal ini dapat dilihat pada saat mereka saling berintraksi dan berkomunikasi dalam penggunaan simbol-simbol tertentu dalam penggunaan bahasa, adanya feedback atau umpan balik yaitu terjadinya arus dari komunikan dan komunikator sehingga adanya perubahan sikap atau komunikasi nonverbal, komunikan dan komunikator sebagai penentu utama keberhasilan dalam komunikasi. Berdasarkan hasil wawancara dengan beberapa narasumber ditemukan bahwa pola komunikasi antarbudaya di Kelurahan Kampung Jawa pola komunikasi bintang. Sebagimana peryataan berikut :

"Paling dominanan masyarakat di kelurahan ini adalah masyarakat yang bersuku Jawa. Pada masyarakat yang memiliki latar belakang budaya yang sama mereka menggunakan bahasa yang sama jika dilihat dari segi bahasa, namun terkadang ada

29 Joseph A. Devito, Komunikaasi Antarmanusia, Edisi ke-5 (Karisma, Publishing Group, Pamulang-Tanggerang Selatan, 2011), h. 294 
juga masyarakat yang berbeda budaya, masyarakat tersebut secara tidak sengaja mengucapkan bahasanya sendiri, tanpa disadarinya masyarakat tersebut menunjukean kebudayaannya sendiri pada orang lain. Jika dilihat dari segi bahasa yang digunakan masyarakat pada umumnya menggunakan bahasa melayu Bengkulu.Di dalam keseharian masyarakat pun tidak ada yang kesulitan dalam penggunannya mungkin karna kebanyakan warga yang menetap di kelurahan kampung Jawa disini memang suku Jawa Tulen namun karna mereka kebanyaakn telah lama tinggal disini jadi mereka fasih berbahasa melayu Bengkulu.Mungkin bukan hanya orang yang bersuku Jawa saja, ada kemungkinan sebagian warga yang bersuku Rejang, Padang, Lembak, Musi juga banyak yang fasib dalam berbahasa sehari-harinya."

Dari wawancara kepada Mirza Fahrizal, hal serupa disampaikan juga kepada Maya Upita sari, selaku masyarakat pendatang bersuku Musi Palembang yang tinggal di kelurahan Kampung Jawa selama 2 tahun ini ia mengungkapkan bahwa:

"Di kelurahan ini lebih dominan dengan orang Jawa, namun banyak, juga pendatang di kelurahan ini seperti orang Lembak, Padang, Palembang dan lain-lain, sebagai pendatang di kelurahan Kampung Jawa keseharian masyarakat disini dalam memperlakukan masyarakat pendatang dilihat baik dalam memperhatikan pertamatama tinggal disini pada saat berintraksi kesehariannya. Meskipun banyak orang bersuku Jawa, namun kami para pendatang tidak ada kesulitan dalam berkomuikasi secara keseharian hidup bertetangga karna masyarakat pada umumnya mengunakan bahasa melayu Bengkulu, dalam keseharian selama tinggal di kelurahan ini budaya yang ada mempengarubi atau bisa dibilang ada perubahan yang dirasakan, misalnaya pada saat pulang ke dusun (kampung halaman), bahasa yang sering digunakan keseharian disini jadi sering terucap, seperti kalau bahasa musi, kamu (nga), jadi sering ngomong(berkata), kau (kamu) dalam bahasa melayu Bengkulu, lebih banyak terucap bahasa melayu Bengkulu jikea pulang ke dusun (kampung halaman). Namun apabila mereka sesama suku Jawa, biasanya mereka bahasa mereka sendiri pada saat berkomunikasi. "'30

Berdasarkan hasil wawancara dari informan dalam penelitian bahwa pada saat komunikasi antara masyarakat pribumi di kelurahan Kampung Jawa dengan masyarakat pendatang mereka satu sama lain memahami, mengerti maksud dalam mengirim pesan pada saat komunikasi berlangsung, karena semua warga menggunakan bahasa melayu Bengkulu tidak menggunakan bahasa daerah masing-masing. Sehingga pada saat mereka berkomunikasi berjalan tanpa adanya noise (gangguan).Selain itu masyarakat pribumi di Kelurahan Kampung Jawa juga menerima setiap masyarakat pendatang dengan baik dalam kehidupan sehari-hari mereka tidak memandang berbedaan budaya yang ada.

${ }^{30}$ Maya Upita Sari (Masyarakat), Wawancara, Tanggal 15 April 2018 
Sehingga hal ini juga memudahkan masyarakat pendatang untuk beradaptasi dengan kebudayaan yang ada, keadaan lingkungan, sikap dan tingkah laku warga asli di kelurahan kampung Jawa tanpa adanya hambatan.Komunikasi antarbudaya yang terdapat di kelurahan Kampung Jawa terjadi secara baik diterima. Untuk lebih memahami proses pola komunikasi di Kelurahan Kampung Jawa peneliti telah melakukan wawancara dengan Kasmilawati, selaku masyarakat kelurahan kampung Jawa, ia mengungkapkan bahwa:

"Sehari-hari dalam berkomunikasi kami sebagai pendatang yang bersuku Jawa dalam berbicara degan masyarakat yang lain jarang menggunakan bahasa daerah, dalam suku Jawa ada yang namanya kata-kata kasar dan kata-kata yang halus, saya dengan tetangga berbahasa Jawa jika dengan sesama orang Jawa. Namun jika bukan orang Jawa penyapaan di kesehariannya yang seusia biasanya hanya memanggil nama, jika saya menyapa nama ibu-ibu yang lebih muda dari saya tetangga disini panggilnya dengan sebutan nama anaknya, misalnya mamak Haikal, karna nama anaknya Haikal (mamak/ibu), mamak Rifki, karna nama anaknya Rifki, ada juga yang di panggil ibu sebagian warganya, jika memanggil nama kasar bagi orang Jawa, jika yang lebih tua di panggil mbah, nyai penyapaan seperti itu dianggap halus dalam budaya Jawa. Meskipun kami warga suku Jawa, namun kami memakai aturan budaya kami, di dalam bahasa Jawa memiliki aturan perbedaan kosa kata dan intonasi berdasarkan melihat siapa yang di ajak bicara.Kalau seperti ini jadi lebih sopan dalam berbicara. Bahasa yang sering digunakan di sini kan bahasa Melayu Bengkulu,"31

Dari hasil wawancara peneliti dengan warga kelurahan kampung Jawa pola komunikasi masyarakat kelurahan kampung Jawa terjadi secara teratur adanya komunikan, komunikator, pesan yang disampaikan dapat di pahami atau dimengerti satu sama lain, komunikasi antarbudaya berlangsung tatap muka sehingga timbulnya respon dari ke dua belah pihak yang berkomunikasi. Dapat peneliti analisis dalam penelitian ini ditemukan proses komunikasi yang masuk dalam kategori pola komunikasi yang terjadi di Kelurahan Kampung Jawa yaitu pola komunikasi bintang.

\section{Pola bintang}

Pola komunikasi bintang merupakan pola komunikasi yang menggambarkan semua anggota yang terlibat dalam sebuah organisasi atsau kelompok semua anggota terlibat dalam komunikasi tampa terkecuali. Berikut ini gambar pola bintang sebagai berikut :

${ }^{31}$ Kasmilawati, Wawancara, 22 April 2018 


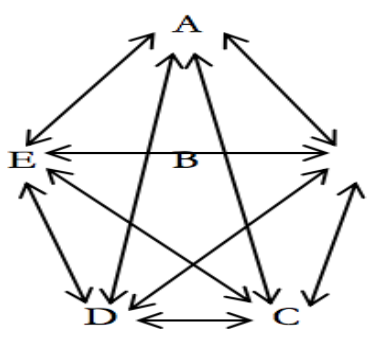

Gambar Pola Bintang

$\begin{array}{lll}\text { Keterangan } & \text { A : Suku Rejang } & \text { D : Suku Jawa } \\ & \text { B : Suku Musi } & \text { E : Suku Padang } \\ \text { C : Suku Lembak } & \end{array}$

Pada gambar pola komunikasi bintang "A" diartikan sebagai suku Rejang sedangkan "B, C, D, dan E" diartikan sebagai masyarakat pendatang seperti Jawa, Padang, Musi Palembang, dan Lembak. Saat berlangsungnya komunikasi semua masyarakat terlibat dalam komunikasi tersebut.Pada gambar 4. 3 arah panah "A" menunjukkan panah yang berbalik arah yang artinya antara "A" (Suku Rejang) berkomunikasi dengan semua masyarakat "B, C, D, dan E" (masyarakat pendatang) menimbulkan feedback atau respon begitu pula sebaliknya arah panah juga berbalik arah pada "B, C, D, dan E" yang mengartikan berkomunikasi juga dengan " $\mathrm{A}$ ". Dapat disimpulkan dari pdnjelasan tersebut setiap anggota dapat berkomunikasi dan melakukan timbal balik dengan semua anggota kelompok yang lainnya.

Dari hasil wawancara maka pola komunikasi yang paling dominan di Kelurahan Kampung Jawa adalah pola komunikasi bintang dimana Masyarakat kelurahan kampung Jawa saling berkomunikasi tanpa ada hambatan satu sama lain antara suku Rejang dengan suku Musi, suku Musi dengan Lembak, suku Lembak dengan suku Jawa, suku Jawa dengan Padang dan seterusnya sehingga hal ini menimbulkan komunikasi terjadi pada semua anggota masyarakat kelurahan kampung Jawa.

Faktor Pendukung Komunikasi Antarbudaya Dalam Proses Komunikasi di kelurahan Kampung Jawa Kecamatan Curup Tengah.

Komunikasi antarbudaya tentu adanya faktor pendukung bagaimana komunikasi di terima secara baik oleh setiap warga yang tinggal di sana baik itu pendatang maupun warga yang menetap.Pada di sana. Kesalahan dalam merespon pesan-pesan yang disampaikan dapat menimbulkan kesalahpahaman maksud dan tujuan satu sama lain individu pada saat berkomunikasi yaitu penggunaan bahasa yang digunakan ketika berkomunikasi. Serta pemahaman tentang adat istiadat yang ada disekitar perlu dipahami agar tidak terjadinya 
permusuhan, perpecahan, konflik sesama masyarkat. Berikut faktor pendukung komunikasi antarbudaya yang ada di Kelurahan Kampung Jawa sebagai berikut :

1. Pesan yang mudah dipahami

Setiap komunikasi yang terjadi akan ada pesan yang akan disampaikan dari komunikator ke komunikan. Agar pesan dapat dengan mudah diterima oleh komunikan, komunikator harus merancang pesan tersebut sebelum dikomunikasikan maksud, tujuan dan isi pesan agar komunikan dapat dengan mudah memahami dan mengerti mkasud dari pesan yang disampaikan. Dalam hal ini komunikasi yang terjadi di Kelurahan Kampung Jawa antara sesama masyarakat yang tinggal di sana menggunakan bahasa Melayu Bengkulu bukan bahasa daerah masing-masing.

Sehingga hal ini memudahkan masyarakat Kelurahan Kampung Jawa dalam berintaraksi dan berkomunikasi.untuk menggetahuinya peneliti telah melakukan wawancara dengan Maya Upita Sari, selaku masyarakat Kelurahan Kampung Jawa ia menggungkapka bahwa :

"Masyarakat di Kelurahan Kampung Jawa selalu menggunakan bahasa melayu Bengkulu untuk berkomunikasi dengan sesama masyarakat yang tinggal di Kelurahan ini, semua fasih dalam penggunaannya meskipun terkadang sebagian masyarakat dalam berbicara gaya bahasanya mencirikan budaya yang dimilikinya seperti orang Jawa berkata "endak kemano"(mau kemana) cengkok Jawa bisa terbaca karna berbicara dengan nada halus. Setiap masyarakat berintraksi secara keseharian atau pada setiap perkumpulan kami warga Kelurahan Kampung Jawa selalu menggunakan bahasa Melayu Bengkulu tidak menggunakan bahasa daerah. Dalam bahasa Musi jikea berbicara dengan yang lebih tua kami memanggilnya "Tubuk"(ibu) secara sopannya, jika seusia kami memanggil "nga"(kamu), penyapaan ini bukan hanya kami pakai untuk sesama orang Musi, sering digunakan dalam sehari-hari. Penyapaan di keseharian di desa ini biasanya saya menyapa melihat suku yang dimilikinya misalnya menyapa orang Rejang "ayuk" (kakak perempuan), mamang (kakak laki-laki), bibik, (bibi), orang Padang jika lebih tua "uni" (kakak perempuan), jika sebaya menggunakan bahasa kami sendiri "nga" (kamu), untuk mengetabui mereka berasal dari mana, melihat dari cara berbicaranya, warna kulitnya, melihat cara berbahasa menggunakan bahasa yang sering digunakan yaitu bahasa melayu Bengkulu. Seperti orang Jawa, jika berbicara Halus, pelan, nadanya rendah, berkulit hitam dan jike mereka berbicara terlihat nada suara orang Jawanya (cengkok). Jadi kami mengetahui babwa mereka orang Jawa "32 
Dari hasil wawancara peneliti dalam komunikasi di Kelurahan Kampung Jawa untuk menyamampaikan suatu pesan setiap masyarakat menjadikan bahasa yang mereka saling pahami sehingga pesan tersebut dapat diterima dengan mudah. Serta komunikasi nonverbal juga menjadi penunjang pesan diterima dengan baik karena setiap seseorang yang akan berkomunikasi secara tidak langsung mereka akan berintraksi satu sama lain sehingga menimbulkan komunikasi verbal. Penyampaian pesan verbal sering kita sampaikan dengan menunjukkan komunikasi non verbal yang beraneka ragam seperti tersenyum, menggerakkan tanggan, menggelengkan kepala, mengangguk, menatap mata, memperhatikan suara lawan berbicaranya, intonasi, dana, gerak isyarat yang di berikan lawan bicaranya dan lain sebagainya sebelum memberikan respon ke lawan bicara. Dalam hal ini kehidupan masyarakat desa kampung Jawa menimbulkan suasana lingkungan dalam bermasyarakat yang harmonis, damai dan tentram serta komunikasi antarbudaya yang efektifitas tanpa adanya hambatan satu sama lain pada saat berkomunikasi di keseharian yang didukung oleh bahasa yang mereka gunakan bahasa yang mudah dipahami bersama yaitu bahasa melayu Bengkulu.

2. Persepsi positif

Pada saat komunikasi berlangsung persepsi seseorang dengan lawan bicara turut mementukan feedback yang akan terjadi. Apabila salah satu dari komunikan maupu komunikator memiliki persepsi negative terhadap lawan bicara tentu hal ini akan menjadi penghambat dalam berkomunikasi. Maka akan ada penerimaan pesan yang disampaikan tidak diterima dengan baik. Persepsi positif dalam berkomunikasi akan menimbulkan perilaku yang baik dengan demikian pesan dalam berkomunikasi dapat saling diterima. Di Kelurahan Kampung Jawa antara masyarakat pendatang dan masyarakat pribumi saling bertoleransi, menghargai adat istiadat yang ada.

Untuk mengetahuinya peneliti telah melakukan wawancara dengan Ibnu Hajar selaku ketua Badan Musyawarah Adat (BMA) ia menggungkapkan bahwa :

"Iika dari segi kebudayaan kegiatan yang berbubungan dengan budaya Rejang yang ada di kelurahan Kampung Jawa ini, di wajibkan menggunakan budaya dari suku Rejang misalnya mengadakan kegiatan yang berbubungan dengan budaya semisalnya "jimpitan" (Budaya Jawa) acara rutinitas kelurahan Kampung Jawa setiap bulannya, dabulu pengumpulan beras, namun sekarang lebih banyak pengumpulan berupa uang, kegiatan ini sepakat dilakukan oleh warga kelurahan Kampung Jawa, untuk membantu warga yang membutubkan serta guna untuk mempererat sirabturahmi seperti pada acara pernikahan setiap acara pernikahan adanya sepatah kata dari saya atau yang mewakili itu namanya "sekapur sirib" (di sampaikan dalam bahasa Rejang), umpama nya "dio ade iben safie daet, ade iben de pici nik, gambea depeak. 
alus, maroba ite kemcep iben yo"( ini ada sirib kami sampaikan (maksudnya kepada rajo( RT, RW Kades, Kadus)), sirih dan gambir ada sedikit, marilab kita mencicipi sirih ini) dan di acara kemalangan, hajatan, arisan pengajian yang masyarakat lakukan itu ada juga istilabnya dikenal dengan "sirib pamitan" yang juga di sampaikan ke dalam bahasa Rejang. Dalam acara pernikaha juga diwajibkan setiap warga membuat "Sawo" (makanan khas suku Rejang berupa ketan) sebagai syarat adat. Meskipun yang mengadakan acara tersebut bukan orang Rejang asli atau tulen dan itu diwajibkan bagi warga kelurahan yang tinggal di kelurahan ini baik itu pendatang, maupun yang sudah menetap. Dan itu di terima baik oleh setiap warga kelurahan Kampung Jawa tidak ada konflik. Dan apabila ada warga yang menolak akan dikenakan saksi adat berupa denda. "33

Secara aturan budaya di Kelurahan Kampung Jawa seluruh masyarakat di wajibkan dalam mematuhi aturan budaya yang ada bagi setiap warga pendatang.Budaya suku Rejang wajib diikuti oleh masyarakat pendatang hal tersebut diterima oleh masyarakat pendatang dengan baik tanpa menilbulkan konflik atau penolakkan. Seperti yang disampaikan oleh Nova selaku warga menetap di Kelurahan Kampung Jawa ia menggungkapkan bahwa :

"Saya tinggal di sini sudah sekitar 6 tahun, sejak menikah. Waktu itu di dalam acara pernikahan saya menggunkan 3 budaya sekaligus, adat Padang, adat Jawa karna suami bersuku Jawa, dan adat Rejang ketika resepsi pernikahan pada saat itu di kediaman suami di kelurahan kampung Jawa ini. Penggunaannya dalam acara pernikahan ini di adat suku Rejang, yang sudah menjadi kebiasaan warga kelurahan kampung Jawa, itu ada yang namany "sekapur sirib”, kata sambutan tegur sapa terhadap tamu ketika mau akad nikah, jike di adat padang menggunakan pakaian adat pernikahan khas padang, dan di adat Jawa menggunkan baju adat. Dalam kesehariannya warga kelurahan kampung Jawa dalam pergaulan bagus, tidak memandang perbedaan. Jika segi budaya memang tradisi adat kebiasaan di kelurahan ini banyak menggunkan adat istiadat Rejang, namun bal ini menurut saya menimbulkan keunik, bagus, senang karna itu tadi saya bukan orang asli suku Rejang suami pun bukan namun diperbolebkan malah waj̈b menggunkan adat istiadat suku Rejang, jadikan bisa menggunkan buday a yang bermacam-macam tidak hanya satu saja jadi lebih bervariasi di acara sebuah penikahan, contoh secara umumnya. Tetapi di kelurahan ini bukan itu saja yang menggunkan adat istiadat suku Rejang masib ada yang lainnya"34

Dari hasil pemaparan wawancara peneliti menganalisis bahwa di Kelurahan Kampung Jawa masyarakat pendatang menjadikan budaya suku Rejang sebagai aturan yang harus dipatuhi di lingkungan sekitar.Tuntutan aturan ini bagi masyarakat pendatang berupakan sebuah penyesuaian diri dengan lingkungan sehingga masyarakat menjadikan hal tersebut sebagai alat beradaptasi dengan budaya yang baru.

\footnotetext{
${ }^{33}$ Ibnu Hajar (Tokoh Masyarakat), Wawancara, Tanggal 22 April 2018

${ }^{34}$ Nova (Masyarakat), Wawancara, Tanggal 27 April 2018
} 
Adaptasi tersebut di terima masyarakat pendatang dengan baik dan menghargai budaya yang ada sehingga dari penerimaan budaya tersebut menimbulkan penerimaan secara positif budaya masyarakat pribumi bagi masyarakat pendatang seperti yang di sampaikan oleh Nova dan Ibnu Hajar sampaikan bahwa setiap masyarakat wajib menggunakan budaya suku Rejang. Dari persepsi positif masyarakat pendatang kebudayaan yang ada di Kelurahan Kampung Jawa menjadikan masyarakat hidup berdampingan secara damai, aman, bertoleransi, harmonis tanpa menimbulkan konflik meski masyarakat pendatang harus mematuhi budaya masyarakat pribumi.

3. Penggunaan bahasa yang sama

Dalam hal ini komunikasi akan berjalan dengan baik antara komunikan dan komunikator perlu memahami bahasa yang di gunakan satu sama lainnya agar tidak terjadinya noise (gangguan). Dari bahasa yang gunakan dalam komunikasi apabila antara komunikan dan komunikator tidak memahami bahasa yang digunakan satu sama lain tentu akan menghambat efektifitas berkomunikasi.

Bahasa merupakan identitas, karena dalam berbahasa terdapat dialek dan aksen yang dapat memperkuat identitas individu.Identitas ini dapat dijadikan pembeda antara ras, entik, budaya, perilaku, adat-istiadat, kelompok budaya, yang dimiliki seseorang dengan individu lainnya.Seperti aku dan dia, aku dan mereka.Begitu pentingnya bahasa dalam berkomunikasi karena tanpa pemahaman bahasa yang digunakan aktivitas komunikasi tidak dapat berfungsi dengan baik.

Seperti yang terjadi di kelurahan Kampung Jawa setiap warga kelurahan berkomunikasi menggunakan bahasa Melayu Bengkulu bukan bahasa daerah masing-masing dan penerimaan budaya yang ada di sana diterima oleh setiap lapisan masyarakat yang mempunyai ras, suku, etnik, yang berbeda.

Untuk mengetahuinya peneliti telah melakukan wawancara dengan Ibnu Hajar selaku ketua Badan Musyawarah Adat (BMA) kelurahan kampung Jawa ia menggungkapkan :

"Di kelurahan Kampung Jawa kebanyakan suku Rejang, Jawa, Padang, Rejang Lembak, dan Musi.Dalam berkomunikasi sehari-hari masyarakat banyak menggunakan bahasa curup atau di kenal dengan sembutan bahasa melayu Bengkulu yang saya lihat selama tinggal disini menjadi ketua Badan Musyawarah Adat. Mereka menggunakan bahasa yang merupakan suku mereka sendiri biasanya dengan sesamanya saja misalnya, Rejang sama Rejang, Padang sama Padang, Jawa sama Jawa dan lain sebagainya. Jarang terlihat yang berbeda suku menggunakan bahasa masing-masing. Dalam menggunakan bahasa tidak ada hambatan dalam komunikasi meskipun kebanyakkan masyarakan di sini yang awam dalam pendidikan namun dalam 
berbahasa alhamdulilah masyarakat kelurahan Kampung Jawa fasih dalam berkomunikasi menggunakan bahasa Melayu Bengkulu"35

Hal yang serupa juga di sampaikan oleh Aprina Yeti selaku masyarakat Kelurahan Kampung Jawa ia menggungkapkan bahwa :

"Dalam sehari-hari jika berkomunikasi dengan sesama masyarakat yang tinggal di kelurahan ini hanya menggunakan bahasa yang biasa digunakan masyarakat pada umumnya bahasa Curup, menggunakan bahasa sendiri bahasa Padang, jarang digunakan meskipun dengan suami sendiri, dan masyarakat sesama orang padang karna banyak kata yang sudah lupa seperti kata "ma etek-etek (sebentar-sebentar), tajilapak (terjatub), ma ili (mengalir) dan lain-lain, lupa maksunya apa, dan telah lama juga menetap di sini dari usia 13 tabun sudah tinggal di kelurahan ini” 36

Dari hasil wawancara peneliti dengan ketua Badan Musyawarah Adat (BMA) dan Aprina Yeti peneliti menganalisis yang menjadi bahasa pemersatu di Kelurahan Kampung Jawa adalah Bahasa Melayu Bengkulu yang mudah dipahami oleh setiap masyarakat Kelurahan Kampung Jawa serta sebagian masyarakat pendatang juga telah lama menetap disana sehingga faktor tempat lingkungan mempengaruhi seperti mereka fasih dalam berbahasa Melayu Bengkulu.

Sehingga pada komunikasi antarbudaya antara masyarakat pendatang dan pribumi satu sama lain memahami maksud dan tujuan pada saat mereka berkomunikasi meskipun dilatarbelakngi oleh budaya yang berbeda. Hal ini menimbulkan keharmonisan, kerukunan dalam kehidupan bermasyarakat di ruang lingkup budaya yang berbeda-beda.

Dari hasil wawancara peneliti memahami bahwasannya dalam komunikasi antarbudaya yang terjadi di kelurahan kampung Jawa setelah melakukan obsevasi dan wawancara maka faktor pendukung yang sangat dominan adalah para warga Kelurahan Kampung Jawa memiliki rasa toleransi dalam kehidupan bermasyarakat, penggenalan dalam pergaulan bagi masyarakat pendatang dilakukan dengan cara yang lebih menyenangkan, berintraksi secara keterbukaan, menciptakan keakraban dan kerukunan seperti mengadakan kegiatan rutinitas keagamaan secara rutin dengan upaya memperkenalkan masyarakat pendatang kepada masyarakat yang lainnya. Serta sebagai masyarakat pendatang mereka memerima kebudayaan yang ada di Kelurahan Kampung Jawa sana sesuai semboyan yang mereka gunakan yaitu "Dimana Bumi Dipijak, Diitu Langit Dijunjung".

Dalam hal ini kehidupan masyarakat kelurahan kampung Jawa menimbulkan suasana lingkungan dalam bermasyarakat yang harmonis, damai dan tentram serta komunikasi antarbudaya yang efektifitas tanpa adanya

35Ibnu Hajar (Tokoh Masyarakat), Wawancara, Tanggal 22 April 2018

36 Aprina Yeti, Wawancara, 26 April 2018 
hambatan satu sama lain pada saat berkomunikasi di keseharian yang didukung oleh bahasa yang mereka gunakan bahasa yang mudah dipahami bersama yaitu bahasa melayu Bengkulu.

\section{Kesimpulan}

Berdasarkan hasil penelitian tentang pola komunikasi antarbudaya masyarakat di kelurahan Kampung Jawa kecamatan Curup Tengah kabupaten Rejang Lebong dapat disimpulkan sebagai berikut :

1. Pola komunikasi antarbudaya di kelurahan Kampung Jawa kecamatan Curup Tengah kabupaten Rejang Lebong adalah pola komunikasi bintang. Pola komunikasi bintang adalah pola komunikasi yang menggabarka bahwa seluruh anggotanya berkomunikasi satu sama lain tanpa adanya hambatan.

2. Faktor pendukung komunikasi antarbudaya di kelurahan kampung Jawa yakni

c. pesan yang mudah dipaham. Dalam berkomunikasi antar masyarakat pribumi dan pendatang mereka sama-sama memahami pesan yang disampaikan dikarnakan mereka menggunakan Bahasa yang mudah di pahami dan di mengerti bersama yaitu Bahasa melayu Bengkulu bukan menggunakan Bahasa daerah masing-masing.

d. persepsi positif. Di kelurahan Kampung Jawa masyarakat memandang secara positif budaya yang digunakan sebagai masyarakat pendatang yang wajib menggunakan budaya suku Rejang dalam kegiatan-kegiatan yang akan di lakukan pada umumnya seperti acara pernikahan, sunatan, acara kemalangan dan lain sebaginya.

e. penggunaan bahasa yang sama. Dalam berkomunikasi masyarakat Kelurahan Kampung Jawa menggunakan Bahasa yang menjadi Bahasa pemersatu bagi masyarakat pribumi dan masyarakat pendatang yaitu menggunakan Bahasa melayu Bengkulu bukan Bahasa daerah masing-masing.

\section{Daftar Pustaka}

Cangara, Hafied, Pengantar Ilmu Komunikasi, Jakart: PT. Raja Grafindo Persada, 1998)

KBBI, Departemen Pendidikan dan kebudayaan, (Jakarta : Balai Pustaka, 1996)

Devito, Joseph A, Komunikasi Antarmanusia, (Tanggerang Selatan: Karisma Publishing Group Bahasa Indonesia, 2011)

Koentjaradinigrat, Metode-Metode Penelitian Masyarakat, (Jakart: Gramedia, 1997)

Komalasari, Bakti. Tessa Naumi, Adinda, Komunikasi Antarbudaya,(Curup: Lp2 STAIN Curup, 2013) 
174 | Jurnal Dakwah dan Komunikasi, Vol. 3 No. 2, 2018

Komaruddin, Metode Penelitian kualitatif,(Yogyakarta: Tiara Wacana, 1999)

Liliweri, Alo, Dasar-Dasar Komunikasi Antarbudaya,(Yogyakarta: Pustaka Pelajar, 2002)

Liliweri, Alo, Gatra-Gatra Komunikasi Antarbudaya,(Yogyakarta : Pustaka Pelajar, 2011)

Moleong, Lexy J,Metodologi Penelitian Kualitatif, (Edisi Revisi Bandung: PT. Rosda Karya, 2006)

Morissan,Teori Komunikasi kominikator, pesan, percakapan, dan hubungan interpersonal,(Bogor: penerbit Ghalia Indonesia, 2013)

Muhadjir, Noeng, Metodologi Penelitian Kualitatif, (Yogyakarta: Rake Sarasin, . 1998)

Mulyana, Deddy, Jalaluddin Rahmat, Komunikasi Antarbudaya Panduan Komunikasi Dengan Orang-orang Berbeda Budaya,(PT. Remaja Rosdakarya Bandung, 2014)

Nawawi, Handari, Metodologi Penelitian Bidang Sosial, (Yogyakarta: Gajah Mada University Press, 1990)

Sugiyono, Metode Penelitian Kuantitatif Kualitatif dan R \&D, (Bandung: Alfabeta, 2014)

Suprapto, Tommy, Pengantar Teori Komunikasi,(Yogyakarta : Media Pressindo, 2006)

Syarnubi, Sukarman. Metodologi Penelitian Kuantitatif dan Kualitatif, (Lembaga Penerbit dan Percetakan (Lp2) STAIN Curup , 2016)

Tubb, Stewart L. Moss, Sylvia.,Human Comunication Konteks-konteks Komunikasi, (Bandung: PT. Remaja Rosdakarya, 2005)

Uchjana, Onong,Ilmu Komunikasi Teori dan Praktek, (Bandung: PT. Remaja Rosdakarya, 2013)

Wijaja, H.A.W, ilmu Komunikasi pengantar studi, (Jakarta: PT. Rineka Cipta, 2000)

\section{Informasi dari internet}

http:// www.irmanfsp.com/2017/03/pola-komunikasi-antar-budaya.html, di akses 07 maret 2017

http://markasfisika.blogspot.com/2017/12/pengertian-subyek penelitiankualitatif.htmldi akses 12 april 2017 